\title{
Progressively restricted expression of a homeo box gene within the aboral ectoderm of developing sea urchin embryos
}

\author{
Lynne M. Angerer, ${ }^{1,3}$ Gregory J. Dolecki, ${ }^{2}$ Michael L. Gagnon, ${ }^{1}$ Richard Lum, ${ }^{2}$ Gordon Wang, ${ }^{2}$ Qing \\ Yang, ${ }^{1}$ Tom Humphreys, ${ }^{2}$ and Robert C. Angerer ${ }^{1}$ \\ ${ }^{1}$ Department of Biology, University of Rochester, Rochester, New York 14627 USA; ${ }^{2}$ Pacific Biomedical Research Center, \\ University of Hawaii, Honolulu, Hawaii 96813 USA
}

\begin{abstract}
A homeo box-containing gene, Hbox1 is expressed in an unusual and highly conserved spatial pattern in embryos of two different species of sea urchin, Tripneustes gratilla and Strongylocentrotus purpuratus. Hybridization in situ shows that this mRNA accumulates initially throughout the aboral ectoderm; however, between blastula and pluteus stages, the region containing Hbox1 mRNA retracts gradually until only a small area around the vertex is labeled in pluteus larvae. Aboral ectoderm appears cytologically uniform and also accumulates uniform levels of other tissue-specific mRNAs. Therefore, the Hboxl pattern reveals a previously unsuspected heterogeneity of aboral ectoderm cells and a polarity within this tissue. In S. purpuratus, the Hbox1 gene product probably is not involved in initial specification of cell fate, as this message does not achieve a significant fraction of its peak abundance until almost hatching blastula stage, well after the time aboral ectoderm cells have initiated a tissue-specific program of gene expression. RNA blot and RNase protection analyses revealed low levels of Hbox1 mRNA in all adult tissues examined. However, this message was not detectable in mature eggs, suggesting that the Hboxl gene does not have a maternal function. In addition to highly conserved spatial and temporal patterns of expression, the homeo box genes of these two urchin species also are conserved highly in sequences outside the homeo domain, despite the divergence of these two species (30-45 my). Two notable features of the protein shared with several vertebrate homeo proteins are a short conserved sequence encoded by an exon upstream of that encoding the homeo domain and a large region of high serine and proline content.
\end{abstract}

[Key Words: Homeo box; sea urchin; developmental regulation; in situ hybridization]

Received December 8, 1988; revised version accepted January 26, 1989.

Genes bearing homeo box sequences encode nuclear proteins with important regulatory functions in a wide variety of organisms, including Drosophila, mouse, and yeast (for review, see Levine and Hoey 1988). In Drosophila and presumably in other organisms, many of these genes function in the control of early developmental programs. Now, there is compelling evidence that homeo proteins function as transcription factors regulating the expression of other genes. In addition to earlier findings that these proteins are nuclear (Kessel et al. 1987; Odenwald et al. 1987; for review, see Gehring $1987 \mathrm{~b}$ ) and that several bind DNA directly in vitro (Desplan et al. 1985, 1988; Fainsod et al. 1986; Beachy et al. 1988), homeo domain binding sites have now been identified in the cis-regulatory sequences of genes regulated

${ }^{3}$ Corresponding author. by homeo box genes (Beachy et al. 1988; Hoey and Levine 1988), and homeo proteins have been shown to be transcriptional activators of the growth hormone and prolactin genes in rat pituitary (Bodner et al. 1988; Ingraham et al. 1988).

Although the DNA-binding domain specified by the homeo box is clearly an ancient and conserved function, much less clear is the extent to which the specific developmental functions of individual homeo proteins, or sets of homeo proteins, have been conserved in embryos of groups as widely separated as insects and vertebrates. Genetic analyses have demonstrated clearly that in Drosophila, homeo box genes are part of the hierarchical regulatory program that controls embryonic segment number, polarity, and identity (for recent reviews, see Akam 1987; Gehring 1987a; Scott and Carroll 1987). A critical aspect of this mechanism is specification of fate of individual regions of the embryo by specific combina- 
tions of gene products, most of which are expressed in strikingly restricted spatial patterns. In vertebrate embryos as well, the most notable feature of expression of homeo box genes is spatial restriction, which demarcates 'regions' of these embryos that do not conform to histological or morphological borders. To date, homeo box gene expression in vertebrate embryos has been observed primarily in dorsal tissues in variably restricted regions along the anterior-posterior axis (e.g., Carrasco and Malacinski 1987; Condie and Harland 1987; Deschamps et al. 1987; Krumlauf et al. 1987; Rubin et al. 1987; Toth et al. 1987; Utset et al. 1987; Gaunt 1988; Holland and Hogan 1988a; Sharpe et al. 1988). However, to date, the regions specified in vertebrates bear no clear relationship to segmentation (Holland and Hogan 1988a). The identification of homeo box sequences in two unsegmented invertebrates, the sea urchin (Dolecki et al. 1986) and Caenorhabditis (Way and Chalfie 1988), further emphasizes that the homeo proteins of diverse organisms may operate in different developmental contexts.

Studies of homeo box genes in the sea urchin embryo, an enterocoelous form that is the ancestral type for both chordates and vertebrates (Hyman 1951), should contribute to elucidating the diversity of homeo box gene functions in development, especially those assumed in embryos on the vertebrate line. The genome of the sea urchin Tripneustes gratilla has been shown to contain at least six different genes containing Antennapedia (Antp) class homeo boxes, which fall into three of the categories of evolutionarily diversified homeo boxes found in Drosophila (Dolecki et al. 1986, 1988; Dolecki and Humphreys 1988). One of these genes, TgHboxl (HB1, Dolecki et al. 1986), is most closely related to the Antp class. (The designation Hbox 1 does not imply structural or functional homology to Hbox 1 of Xenopus.) The TgHboxl gene encodes a 6.9-kb transcript that is first detectable at blastula stage, increases severalfold in abundance at gastrula stage, and then decreases to blastula-stage levels in the pluteus larva. It also encodes a less abundant $7.7-\mathrm{kb}$ transcript that is detectable only at gastrula stage. Transient expression of mRNAs and the production of multiple transcripts are characteristic of homeo box genes in both Drosophila (for review, see Akam 1987; Gehring 1987a; Scott and Carroll 1987) and vertebrate (Condie and Harland 1987; Odenwald et al. 1987; Rubin et al. 1987; Fritz and DeRobertis 1988) embryos.

In this discussion we show that Hboxl is expressed in an unusual pattern in the aboral ectoderm of $T$. gratilla and Strongylocentrotus purpuratus embryos. Although, by other molecular and cytological criteria, aboral ectoderm is a uniform region containing a single cell type, as development proceeds Hboxl mRNA becomes progressively restricted to a small region corresponding closely to that derived from one blastomere of the eight-cell embryo. The temporal and spatial patterns of expression of Hboxl, as well as protein sequence outside the homeo domain, are highly conserved between these two urchin species, which diverged 30-45 million years ago (Smith
1988), and this gene also shares features with vertebrate homeo box gene sequences.

\section{Results \\ Temporal pattern of Hbox 1 expression during development}

Previous studies have shown that the Hboxl gene of $T$. gratilla (TgHboxl) encodes a polypeptide containing a homeo domain that has $88 \%$ amino acid sequence similarity to that of the Drosophila Antp class and that expression of this gene is regulated during embryogenesis (Dolecki et al. 1986). Under sufficiently stringent conditions $\left(\sim T_{m}-15^{\circ} \mathrm{C}\right)$, a probe containing the $T$. gratilla homeo box plus significant $3^{\prime}$-untranslated sequence (probe 1, Fig. 1) hybridizes to a single fragment of T. gratilla genomic DNA digested with either EcoRI or HindIII, as shown in Figure 2, lanes 1 and 2. Similar results are obtained when probe 1 is hybridized under the same conditions to digests of $S$. purpuratus DNA (Fig. 2, lanes 3 and 4). We believe that the minor bands in the latter blot represent a polymorphism present at low frequency in this sample of $S$. purpuratus DNA, which was derived from an unknown number of individuals. These data suggest that the TgHboxl probe hybridizes with a single gene in both of these genomes under moderately stringent conditions.

In preliminary experiments to determine whether Hboxl also is expressed in $S$. purpuratus embryos, we hybridized RNAs at similar stringency transcribed from T. gratilla template 1 (Fig. 1) to blots of total RNA from different stages of $S$. purpuratus embryos. This revealed only a single $6.2-\mathrm{kb}$ mRNA whose time course of accumulation is quite similar to that of the message encoded by Hboxl in T. gratilla embryos. This message is not detectable until stages between hatching and mesenchyme blastula; it then increases in abundance during gastrulation and subsequently decreases in the pluteus larva (data not shown; see Table 1). Additional evidence

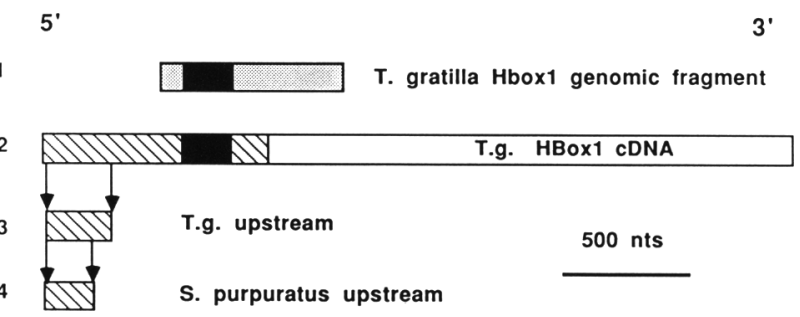

Figure 1. Probes for Hbox 1 mRNAs. Probes 1-3 are T. gratilla sequences. The homeo box is indicated by solid bars, translated sequence by hatched bars, untranslated mRNA sequence by an open bar, and intron sequence by stippled bars. (Probe 1) An EcoRI-HaeIII fragment from a genomic DNA clone containing the homeo box and a portion of the upstream intron. (Probe 2) The 3361-bp cDNA clone, whose sequence is presented in Fig. 8. (Probe 3) An EcoRI-PstI fragment containing the 284 bp at the $5^{\prime}$ end of probe 2. (Probe 4) A 226-bp TaqI fragment from an $S$. purpuratus genomic DNA clone whose sequence is shown aligned with that of the T. gratilla cDNA in Fig. 8. 


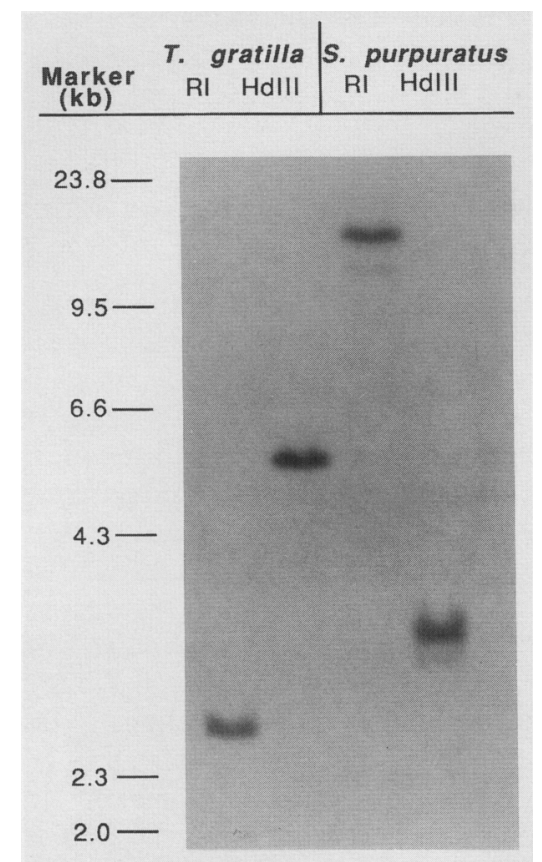

Figure 2. Hybridization of the T. gratilla homeo box probe to restriction endonuclease digests of genomic DNA from $T$. gratilla (first and second lanes) and $S$. purpuratus (third and fourth lanes). DNAs were digested with either HindIII (second and fourth lanes) or $E c o \mathrm{RI}$ (first and third lanes) and hybridized with nick-translated probe 1 (Fig. 1). The T. gratilla DNA was prepared from the sperm of a single individual; the $S$. purpuratus DNA, from the sperm of an unknown number of individuals. Posthybridization washes were at $\sim 15^{\circ} \mathrm{C}$ below the melting temperatures of homologous duplexes. that this $S$. purpuratus mRNA is transcribed from the gene that is homologous to TgHboxl is provided by the observation that an mRNA of the same size was also detected by a probe (transcribed from template 4, Fig. 1) containing only $S$. purpuratus sequence upstream of the homeo box (data not shown).

The absolute number of Hboxl transcripts in S. purpuratus embryos at several stages was determined for two different cultures by titration with an excess of labeled antisense RNA probe (Lynn et al. 1983) transcribed from $T$. gratilla template 1 (Fig. 1). (RNase protection experiments with the $\mathrm{TgHboxl}$ probe, similar to those shown in Figures 5-7 using the $S$. purpuratus probe, revealed only a protected fragment of $\sim 180$ nucleotides, presumably corresponding to the homeo box sequence.) These titration data, listed in Table 1, demonstrate that the $S$. purpuratus mRNA has the same temporal pattern of expression during embryogenesis as was defined previously for the 6.9 -kb message in embryos of $T$. gratilla by RNA blot analysis (Dolecki et al. 1986). In addition, a reproducible severalfold difference in Hboxl mRNA levels was observed in S. purpuratus embryos from the two different cultures. Embryos in both cultures appeared morphologically normal and developed at the same rate. As a control, the abundance of actin CyIIIa mRNA, which accumulates in the same cell type as does Hboxl message (see below), was measured and found to be quite similar in both cultures (Table 1). These data suggest that Hbox 1 mRNA levels may not be subject to precise quantitative control during development. In $S$. purpuratus, the Hboxl mRNA is abundant moderately at the time of its maximal accumulation, comprising $\sim 0.04-0.1 \%$ of total embryo mRNA.

Table 1. Quantitation of Hbox1 mRNA in S. purpuratus embryos

\begin{tabular}{|c|c|c|c|c|}
\hline \multirow[b]{2}{*}{$\mathrm{Hr}$} & \multicolumn{2}{|c|}{$\begin{array}{l}\text { Number of transcripts } \\
\text { per embryo }\left(\times 10^{-3}\right)\end{array}$} & \multirow{2}{*}{$\begin{array}{l}\text { Approximate number of } \\
\text { cells expressing } \\
\text { Hbox } 1\end{array}$} & \multirow{2}{*}{$\begin{array}{c}\text { Approximate number of } \\
\text { mRNAs/cella }\end{array}$} \\
\hline & Hboxl & CyIIIa & & \\
\hline \multicolumn{5}{|c|}{ Culture 1} \\
\hline 19 & 2.5 & 17 & $\mathrm{ND}^{\mathrm{b}}$ & $\mathrm{ND}^{\mathrm{b}}$ \\
\hline 23 & 6.6 & 110 & 160 & 40 \\
\hline 48 & 9.3 & 127 & 280 & 30 \\
\hline 72 & 4.5 & 119 & $80-100$ & $45-55$ \\
\hline \multicolumn{5}{|c|}{ Culture 2} \\
\hline 23 & 19 & 114 & 160 & 120 \\
\hline 29 & 22 & 102 & $\mathrm{ND}^{\mathrm{b}}$ & $\mathrm{ND}^{\mathrm{b}}$ \\
\hline 41 & 25 & 93 & $\mathrm{ND}^{\mathrm{b}}$ & $\mathrm{ND}^{\mathrm{b}}$ \\
\hline 48 & 13 & 95 & 280 & 45 \\
\hline 72 & 10 & 89 & $80-100$ & $100-125$ \\
\hline
\end{tabular}

The number of cells expressing SpHboxl mRNA was estimated as follows: It was assumed that most of this mRNA is in aboral ectoderm cells (see Fig. 3). Blastulae ( $23 \mathrm{hr}$ ) contain $\sim 200$ aboral ectoderm cells and most, if not all, accumulate SpHboxl; gastrulae contain $\sim 350$ aboral ectoderm cells, of which $\sim 80 \%$ are labeled; and plutei contain $\sim 400$ aboral ectoderm cells, of which about one-quarter to one-fifth are labeled.

b(ND) Number of cells containing SpHbox 1 mRNA was not determined by in situ hybridization. 
An unusual spatial pattern of expression of Hbox 1 is conserved between $\mathrm{S}$. purpuratus and $\mathrm{T}$. gratilla

The distribution of Hbox 1 mRNA was determined by in situ hybridization of ${ }^{35} \mathrm{~S}$-labeled RNA transcribed from template 1 (Fig. 1), representing the $T$. gratilla homeo box sequence, to sections of eggs and embryos of both species. Consistent with solution hybridization measurements (Fig. 7), no signal was observed in unfertilized eggs or 12-hr embryos. Sections of blastulae, gastrulae, and plutei of $T$. gratilla (rows 1, 2, 4, and 5) and S. purpuratus (rows 3 and 6) are shown in Figure 3. At all stages at which this gene is expressed, the mRNA is found in differentiating aboral ectoderm cells. Aboral ectoderm can be identified cytologically in late gastrula and pluteus stages, and its progenitor cells can be defined at earlier stages in $S$. purpuratus embryos by their content of several specific mRNAs including Spec1 (Lynn et al. 1983) and actin CyIIIa (Cox et al. 1986).

Hboxl transcripts are detected first in blastula-stage embryos in a region with size and shape characteristic of presumptive aboral ectoderm (Fig. 3). At gastrula stage, a large fraction, but not all, of the presumptive aboral ectoderm contains detectable Hboxl mRNA. This observation was confirmed by analyzing a series of adjacent $1-\mu \mathrm{m}$ sections of $S$. purpuratus gastrulae hybridized alternately with probes for either Hbox 1 mRNA or CyIIIa actin mRNA, which labels the entire region of aboral ectoderm at all stages from blastula to pluteus (Cox et al.

Figure 3. Spatial pattern of expression of Hboxl mRNAs in $T$. gratilla and $S$. purpuratus. RNA probes labeled with ${ }^{35} \mathrm{~S}$, transcribed from template 1 (Fig. 1), were hybridized in situ to sections of blastulae, gastrulae, and plutei. (Row 1) Phase-contrast images of $T$. gratilla embryos, including a blastula and gastrula that have been sectioned approximately perpendicular to the animal-vegetal axis, with the presumptive aboral side to the right. The early pluteus (prism) has been sectioned through the plane of bilateral symmetry, and the vertex is at the bottom. (Row 2) Labeling pattern of the same sections in dark-field illumination. Regions of different labeling intensity are evident in the presumptive ectoderm. (Row 3) Sections of $S$. purpuratus embryos in orientations approximately the same as the corresponding stages shown in rows 1 and 2. (Rows 4-6) The same series, but in each case, the plane of sectioning is approximately orthogonal to that in rows $1-3$. Labeling of two crescents on either side of the blastula in sections cut close to the border between presumptive oral and aboral ectoderm (marked by the arrowheads in row 6) is diagnostic for the aboral ectoderm tissue in S. purpuratus (Lynn et al. 1983). In the sections of gastrula, presumptive aboral ectoderm lies on the left side. The sections of plutei are cut approximately parallel to the anal side, and the oral faces are at the top. The margin between oral and aboral ectoderm in the plutei of rows 3 and 6 is indicated by arrowheads. Plutei of $T$. gratilla expand considerably more and extend longer arms than do those of $S$. purpuratus. This section is cut slightly oblique to the anal surface, and extends along much of the right, but not the left, anal arm. Bar in row 1, 10 $\mu \mathrm{m}$.
1986). In the example shown in Figure 4, the labeled region of the middle section that was hybridized with the CyIIIa probe is larger than the most heavily labeled region of the adjacent sections that were hybridized with the Hboxl probe. Comparison of the size of labeled regions in random sections of stages between gastrula and pluteus $(52,65$, and $75 \mathrm{hr})$ shows that as aboral ectoderm differentiates cytologically, the labeled region recedes progressively toward the vertex (data not shown).

At pluteus stage, Hboxl mRNA is detectable in $\sim 20-25 \%$ of aboral ectoderm cells located over the vertex where the two longest skeletal elements converge

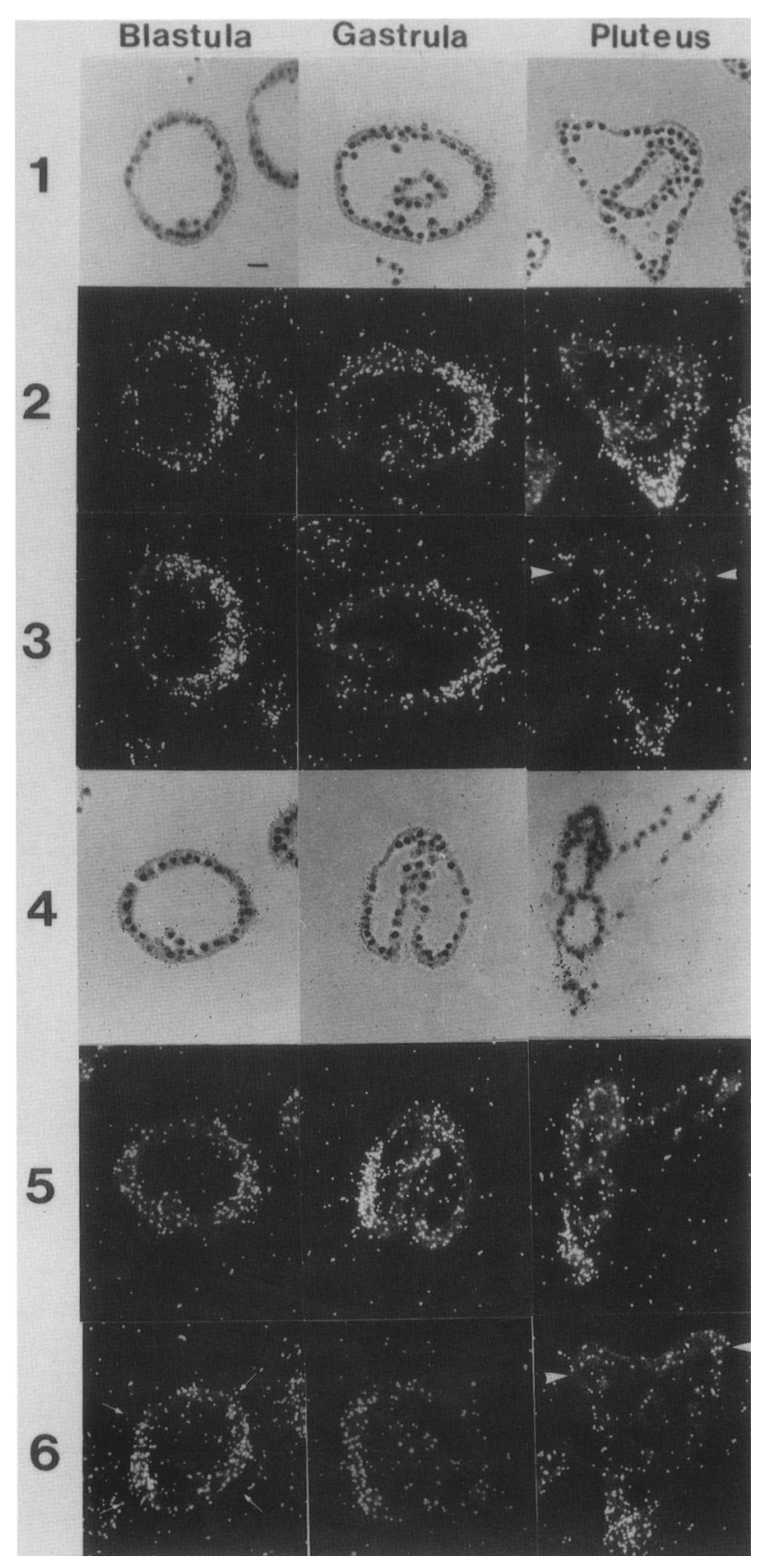




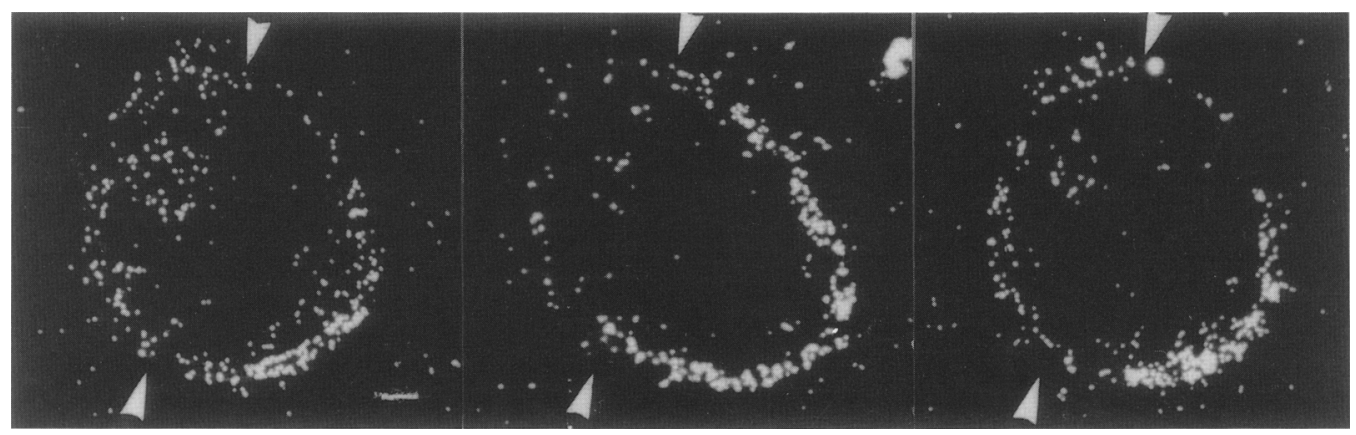

Figure 4. Hbox l mRNA is progressively restricted to ectoderm at the aboral end of the embryo as development proceeds. Adjacent $1-\mu \mathrm{m}$ sections of $S$. purpuratus gastrulae were hybridized alternately with Hboxl probe 1 (left and right sections) or with a probe for CyIIIa actin mRNA (middle section), which labels the entire presumptive aboral region. The margins of the presumptive aboral ectoderm, defined by CyIIIa labeling, are indicated by arrowheads. Labeling with the Hboxl probe is heaviest around the presumptive vertex; grain densities over regions of oral ectoderm and gut are higher than over the immediately adjacent cells, but this is probably due to nonspecific binding of probe (see text and Fig. 5). Bar, $10 \mu \mathrm{m}$.

(see Fig. 9). This was a surprising result, because aboral ectoderm cells have been considered to be a uniform cell type. Cytologically, the cells are similar and five other mRNAs, including several that are expressed uniquely in aboral ectoderm, are distributed uniformly in the entire tissue at all stages when they are expressed (Lynn et al. 1983; Angerer et al. 1986; Cox et al. 1986; Hardin et al. 1988). Thus, the distribution of Hbox 1 mRNA is presently the only indication of a developmental and/or physiological polarity within the aboral ectoderm.

These in situ hybridizations demonstrate that a slow temporal wave of arrest of Hboxl gene transcription and/or mRNA decay proceeds in a direction away from the oral face of the embryo during the $48 \mathrm{hr}$ (for S. purpuratus) of development from blastula to pluteus stage. A gradient of Hboxl mRNA abundance begins to be established soon after the mRNA first accumulates at mesenchyme blastula stage. The arrow in row 2 of Figure 3 marks the region of highest grain density located in the center of presumptive aboral ectoderm. Examination of many sections of gastrulae suggests some heterogeneity in down regulation of Hbox 1 gene expression among different portions of the aboral ectoderm because sometimes there are sharp borders between labeled and unlabeled regions (e.g., Fig. 3, row 2\}, whereas in other sections we observe fringes of intermediate labeling intensity adjacent to the most heavily labeled regions (e.g., rows 2 and 3 ). In favorably oriented sections of gastrulae that pass longitudinally through the archenteron (as in Fig. 3, row 5), the labeling patterns can be interpreted unambiguously with respect to the fate map described by Cameron et al. (1987). The grain densities are highest over the region on the vegetal side of presumptive aboral ectoderm that will form the vertex of the pluteus and is derived from the Va blastomere of the eight-cell embryo (see Fig. 9).

Some sections showed grain densities over tissue, other than aboral ectoderm, that appeared to be above background. Whereas all sections that included appropriate regions showed labeling of aboral ectoderm, labeling of these other regions was much more variable among sections. Because grain densities in these cases were relatively low, we tested for expression in tissues other than aboral ectoderm by tissue-fractionation methods. S. purpuratus gastrulae were separated into two cell fractions, one highly enriched for ectoderm and the other for endoderm plus mesenchyme. Total RNA isolated from each of these fractions was hybridized to a mixture of radioactively labeled antisense RNAs complementary to the SpHboxl mRNA (template 4, Fig. 1) and to Specl mRNA, which is expressed only in aboral ectoderm (Lynn et al. 1983; Hardin et al. 1988). After removal of unhybridized probe with RNase A in high salt, resistant probe was separated by electrophoresis on denaturing polyacrylamide gels and autoradiographic signals were quantitated by densitometry. As shown in Figure 5, the ratio of signals for endoderm plus mesenchyme/ectoderm fractions was not detectably higher for SpHboxl mRNA than that for Specl mRNA, which measures the contamination of the endoderm plus mesenchyme fraction by aboral ectoderm cells. These measurements provide independent evidence that the large majority of SpHboxl mRNA is contained in ectoderm cells and suggest that the low levels of labeling in other tissues in the in situ hybridizations are due to nonspecific binding of probe. We cannot exclude the possibility that some other cells express this gene transiently or occasionally at levels that do not lead to appreciable accumulation.

\section{Expression of Hbox1 in adult tissues and during oogenesis}

The T. gratilla Hboxl gene also is expressed in a variety of adult tissues. An RNA blot of $2 \mu \mathrm{g}$ poly(A) ${ }^{+}$RNA from coelomocytes, ovaries, testes, Aristotle's lanterns, small intestines and large intestines was hybridized with the 3361-nucleotide TgHboxl cDNA probe (Fig. 1, probe 2 ), labeled with $\left[\alpha-{ }^{32} \mathrm{P}\right] \mathrm{dCTP}$ by random priming with oligonucleotides. A single $6.9-\mathrm{kb}$ transcript is present in all adult tissues, as shown in Figure 6A. It is most abundant in small intestine, about twofold less 


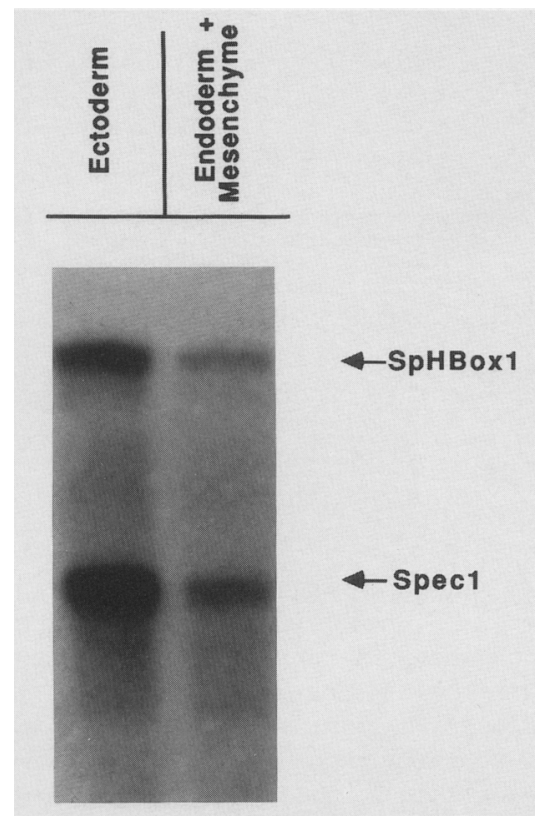

Figure 5. Hboxl mRNA is not detectable in cells other than aboral ectoderm at earlier stages. Transcripts of template 4 (Fig. 1) complementary to the SpHboxl upstream region were used in RNase protection assays to detect complementary mRNAs in fractions of $S$. purpuratus gastrulae enriched for ectoderm (lane 1) or endoderm plus mesenchyme (lane 2). To measure contamination of the endoderm plus mesenchyme fraction with aboral ectoderm, the same reaction mixtures also included a probe for Specl mRNA, which is expressed exclusively in aboral ectoderm. After hybridization of $3 \mu \mathrm{g}$ of each cellular RNA with an excess of probe to kinetic termination, RNase-resistant probes (indicated by arrows) were fractionated by electrophoresis on denaturing $5 \%$ polyacrylamide gels. Probe sp. act. were $1 \times 10^{7} \mathrm{dpm} / \mu \mathrm{g}$ and $5 \times 10^{8} \mathrm{dpm} / \mu \mathrm{g}$ for Specl and SpHbox 1, respectively, to compensate for the large difference in abundance of these messages. Exposure was for $24 \mathrm{hr}$.

abundant in large intestine, Aristotle's lantern, ovary, and testis, and a further twofold less abundant in coelomocyte poly $(\mathrm{A})^{+} \mathrm{RNA}$. To compare directly expression of TgHbox 1 mRNA in embryos and adult tissues, equal quantities of small intestine and gastrula poly $(A)^{+}$ RNAs were analyzed on the same RNA blot. Intestine RNA displayed a band with the same mobility as that of the 6.9-kb embryonic TgHboxl species reported previously (Dolecki et al. 1986), and this transcript was at least 20 times less abundant in RNA from small intestines than from gastrulae (data not shown). Thus, TgHbox 1 mRNA accumulates at levels 20- to 80-fold lower in adult tissues of $T$. gratilla, including ovary, than it does during embryogenesis. The levels of expression of SpHboxl mRNA in total RNA from ovary, unfertilized eggs, and gastrula-stage embryos of $S$. purpuratus also were compared by the RNase protection assay shown in Figure 6B. For this comparison, $20 \mu \mathrm{g}$ (lane G) or $0.4 \mu \mathrm{g}$ (lane g) of gastrula RNA, and $20 \mu \mathrm{g}$ each of ovary RNA or RNA from mature eggs was hybridized to an excess of complementary RNA probe synthesized from the SpHbox 1 template 4 (Fig. 1). The intensities of the protected bands indicate that in $S$. purpuratus as well, the abundance of SpHboxl message in ovary is about 100-fold lower than that in gastrula-stage embryos. However, this message is undetectable in the RNA of mature unfertilized eggs. The data from these assays combined with those of Table 1 show that in both species, ovary contains less than one copy of Hboxl message in an amount of RNA equivalent to that in a typical gastrula cell, and unfertilized eggs of $S$. purpuratus contain, at most, severalfold less than this amount.

Hbox1 mRNA appears in S. purpuratus embryos after aboral ectoderm is determined

Because homeo box genes in Drosophila frequently are involved in early events of specification of cell fate, we examined times when Hboxl transcripts first begin to accumulate in $S$. purpuratus embryos relative to the time of transcriptional activation of two aboral ectoderm-specific mRNAs. In the analysis shown in Figure 7, we used RNase protection assays to quantitate the amounts of SpHbox1 (Fig. 1, probe 4; Fig. 7, top), Spec1 (Fig. 7, middle), and actin CyIIIa (Fig. 7, bottom) messages at the indicated stages of development. Because unfertilized eggs contain traces of maternal Specl and CyIIIa transcripts, the first stage at which signals increase compared to the previous stage provides an estimate of the latest time at which these genes are activated transcriptionally. In the cases of Specl and actin CyIIIa, this occurs between 9 and $12 \mathrm{hr} / \sim 100-$ to 150 cell stage), and new transcripts are detectable and localized in presumptive aboral ectoderm by in situ hybridization at $18 \mathrm{hr}$ (Cox et al. 1986; Hardin et al. 1988). In contrast, Hboxl mRNA does not achieve a significant fraction of its peak abundance until some time after 15 $\mathrm{hr}$ and probably closer to $20 \mathrm{hr}$. Calculations based on the data of Figure 6, which were part of the same set of measurements, indicate that the traces of SpHbox 1 mRNA detectable at $9-15 \mathrm{hr}$ correspond to only $\sim 1 \%$ of the levels at gastrula stage. Assuming that the time of major accumulation of Hboxl transcripts reflects the time of function of the protein, this implies that SpHboxl function is not prerequisite to activation of tissue-specific genes in the aboral ectoderm.

\section{Conservation of Hbox1 sequence outside the homeo box}

Homeo box sequences encode DNA-binding domains linked to other protein domains that may have diverse functions in different organisms. To determine whether the T. gratilla and S. purpuratus Hboxl proteins are similar outside the homeo domains, we compared sequences upstream from this region. Using a $T$. gratilla sequence upstream of the homeo box as probe (Fig. 1, template 3), we recovered a homologous $S$. purpuratus genomic DNA clone. The sequence of the T. gratilla cDNA clone, in- 

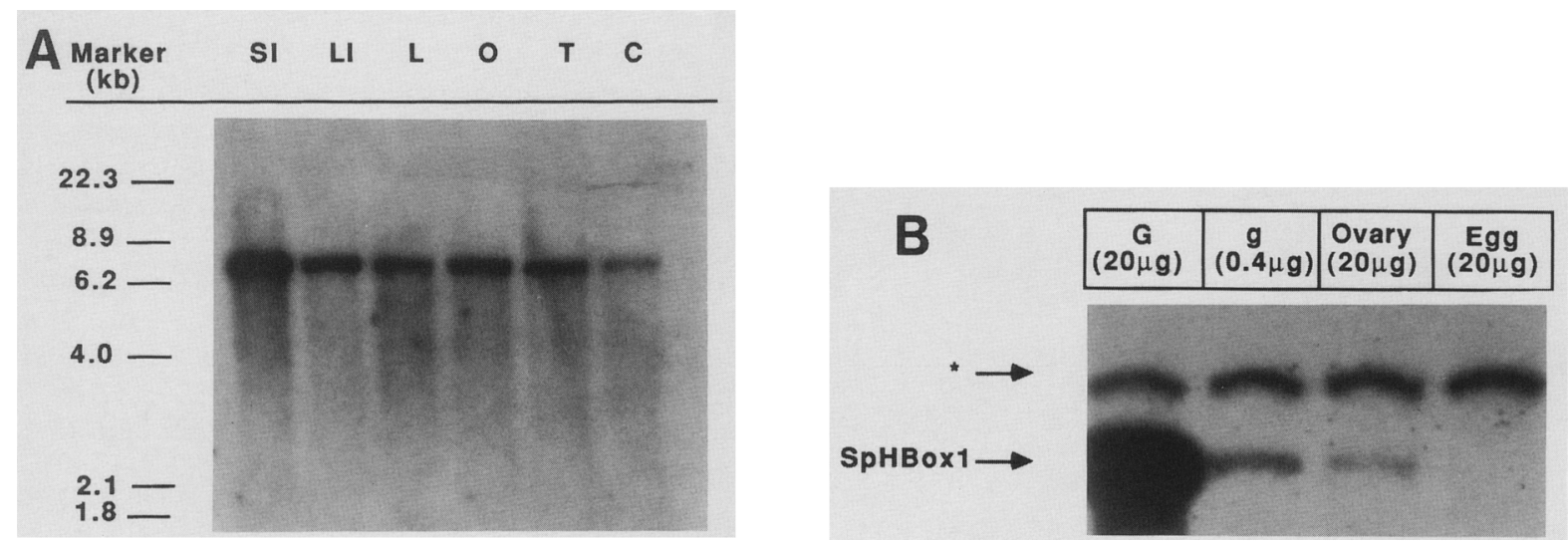

Figure 6. Expression of Hboxl mRNA in adult tissues of $T$. gratilla and in ovary and mature eggs of $S$. purpuratus. (A) RNA blot analysis of $2 \mu \mathrm{g}$ of poly $(\mathrm{A})^{+}$RNA purified from $T$. gratilla coelomocytes $(\mathrm{C})$, testes $(\mathrm{T})$, ovaries $(\mathrm{O})$, Aristotle's lanterns $(\mathrm{L})$, large intestines (LI), and small intestines (SI), hybridized with a $T$. gratilla cDNA probe prepared by random oligonucleotide primed synthesis of template 2 (Fig. 1). (Left) Sizes of denatured HindIII-digested $\lambda$ DNA markers. (B) Comparison of Hbox 1 expression in gastrulae, ovaries, and mature eggs of $S$. purpuratus by RNase protection. Total RNAs from gastrulae $(20 \mu \mathrm{g}$ in lane G and $0.4 \mu \mathrm{g}$ in lane g), ovary $(20 \mu \mathrm{g})$, and mature eggs $(20 \mu \mathrm{g})$ were hybridized to an excess of labeled complementary transcripts of SpHboxl template 4 (Fig. 1) to kinetic termination. Unhybridized probe was digested with RNase, and protected probe was fractionated on a denaturing polyacrylamide gel. The upper band in each of the other lanes $(\star)$ is an unrelated RNA transcript added to each sample after RNase and proteinase $\mathrm{K}$ digestions to measure recovery of the samples during purification. The probe sp. act. was $10^{8} \mathrm{dpm} / \mu \mathrm{g}$, and exposure was $93 \mathrm{hr}$.

cluding a 307-deduced amino acid sequence, is shown in Figure 8 , along with the overlapping $S$. purpuratus genomic sequence. The nucleic acid sequences upstream of the homeo box are $86 \%$ similar. There are two gaps in the $S$. purpuratus sequence relative to the T. gratilla sequence, each of which deletes a codon and thus maintains the reading frame. Eighty percent ( 24 of 30 ) of the nucleotide sequence differences are silent third-base changes resulting in deduced amino acid sequences that are $93 \%$ similar. This region of the protein has an unusually high content of serine $(18 \%)$, threonine $(10 \%)$, glycine $(9 \%)$, and proline $(9 \%)$, accounting for $45 \%$ of the residues. Local regions show even higher concentrations of these individual amino acids. For example, nucleotides 101-200 encode $36 \%$ serine, and 201-300 encode $24 \%$ proline. The underlined sequence Gly-TyrPro-Trp-Met matches four of five positions in a consensus sequence found in similar position just upstream of the homeo domain in several other proteins (discussed in Mavilo et al. 1986; Krumlauf et al. 1987; Fritz and DeRobertis 1988).

\section{Discussion}

The spatial pattern of expression of the Hboxl gene in $T$. gratilla and $S$. purpuratus shares a number of features with that of homeo-box-containing genes in embryos of other organisms (for Drosophila review, see Scott and Carroll 1987; for Xenopus examples, see Carrasco and Malacinski 1987; Condie and Harland 1987; for mouse review, see Holland and Hogan 1988b). As a deuterostome, the sea urchin is allied most closely to the vertebrates, and its enterocoelous embryo is representative of the ancestral type for chordate and vertebrate embryos

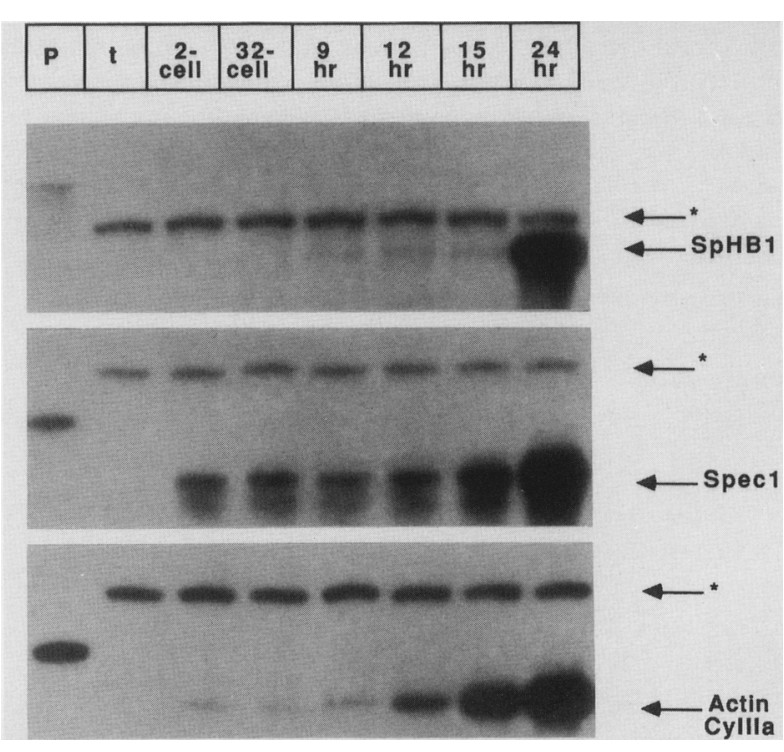

Figure 7. Time of accumulation of SpHboxl mRNA and two aboral ectoderm-specific mRNAs in $S$. purpuratus embryos. Total RNA was extracted from embryos at the stages indicated above the lanes. The concentrations of Hboxl (top), Specl (middle), and actin CyIIIa (bottom) mRNAs were determined by RNase protection measurements with labeled RNA probes, as described in the legend to Fig. 6 and Methods. (Lane $t$ ) Yeast tRNA was substituted for sea urchin RNA. (Lane P) Size of the probe without hybridization or RNase digestion; arrows indicate positions of protected probe. The upper bands in each panel are labeled transcripts added after RNase digestion to monitor recovery of the samples during processing. Probe sp. act. were $1 \pm 0.1 \times 10^{8} \mathrm{dpm} / \mu \mathrm{g}$, and exposure times were $70.5,4$, and 12 hr for SpHboxl, Specl, and actin CyIIIa, respectively. 


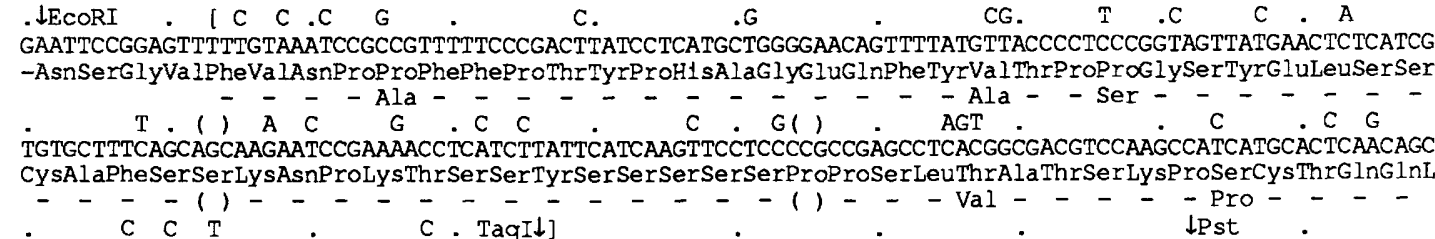
TCGGCGCTGCTACCTTTTACGGTGGAGGACGTTATCGACTTTTCGACAGCGGGTTACGGCGATCACTCAACAACGTCTGCAGGTIACGGGTCCATGTC euGlyA laAlaThrPheTyrGlyGlyGlyThILeuSerAsnPheSerThrAl aGlyTyrGIyAspH IsSerThrThrSerAlaGlyTyrGlySerMetSe - - - - - - - - -

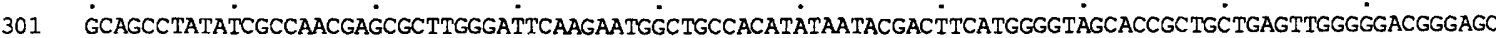
rGlnProI leSerProThrSerAl aTrpAspSerArgMet AlaAlaThrTyrAsnThrThrSerTrpG lySerThrA laAlaGluLeuGlyAspGlySer

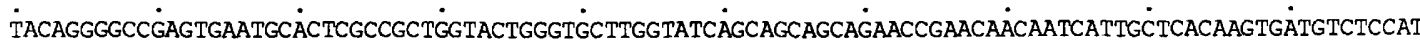
TyrArgGlyArgVa IAsnAlaLeuAlaAlaGlyThrGlyCys LeuValSerAlaAlaAlaGluProAsnAsnAsnH1sCysSerGlnValMetSerPro ĠAAATCTACCंTCAGGATATCCATGGATGCCAGTAGCAGGTCCTAATGTTGंGTCTTGAAGTCGGCAGGAAÄAGATGTCGGCAGACCTACAC̈CCGCTACCA ysLysSerThrSerGIyTyrProTroMetP roValA laGlyProAsnVal Gl yLeuGluValGlyArgLy sArgCy sArgGlnThrTyrThrArgTyrGI

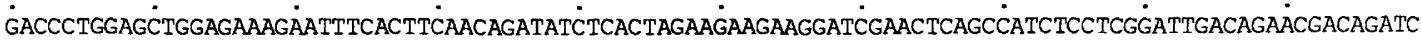
nThrLeuGluLeuGluLy SGluPheH is PheAsnArgTyrLeuThrArgArgArgArg IleGluLeuSerH1 sLeuLeuGly LeuThrGluArgGlnIIe

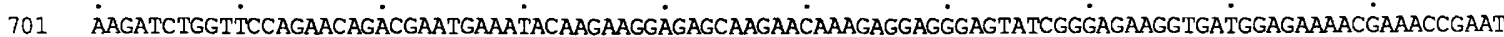
LysI IeTrPPheGInAsnArgArgMet Iy S TyrLys LysGluSerLysAsnLy SGluGluGlyVa ISerGlyGluGlyAspGlyGluAsnGluThrGluS

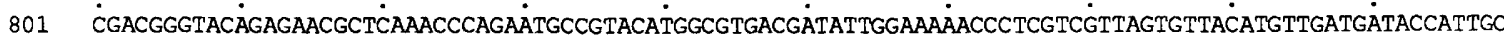
erThrGlyThrGluAsnAlaGlnThrGlnAsnAlaValH1sGlyValThrIleLeuGluLys ProSerSerLeuVal LeuH1sValAspAspThrIleAl

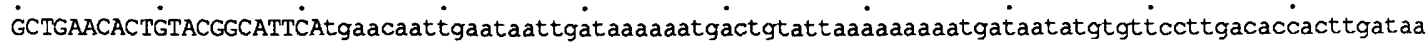
aLeuAsnThrValArgH1sSer

$001 \dot{\text { tttatacttacaaataaactaaaatagtcaggggattcattgaagagtttatgttgaacccaagggtat } \dot{t} a t c a t a t c a \dot{t} a t t g t g a t g \dot{t} t a t t g t g t g}$

101 tgtgtgtgtctgtcacctggttgtaaatagtaatatgaaaactcgatgtgtaaattatgtatataatctctggactccatgtgtatagagaaagaaacac

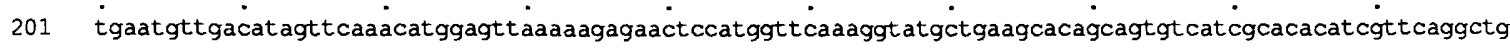

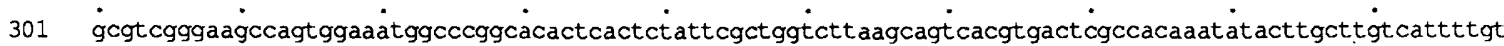

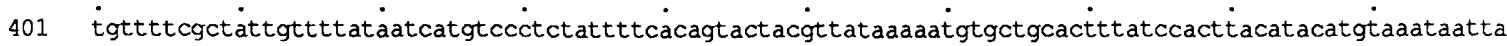

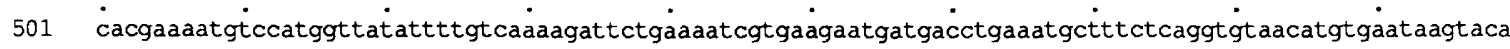

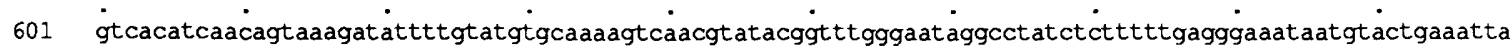
701 taattttgcatattattatagtattaaaaaaatcaaacgattataatttgtgagaagtgt $\dot{c}$ cgactcggtaaatggcagcaaaatcactcctatccctcca

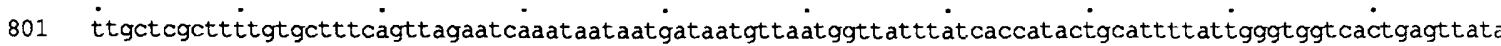

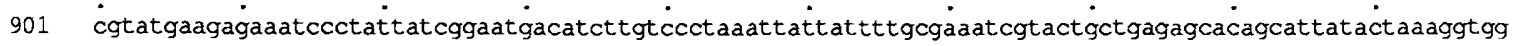

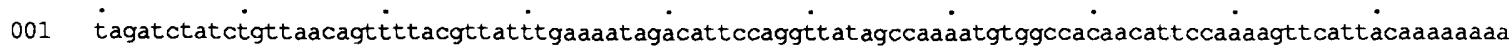

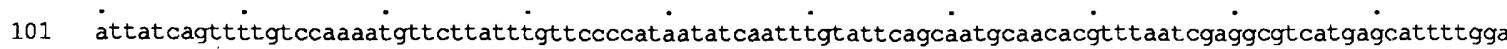

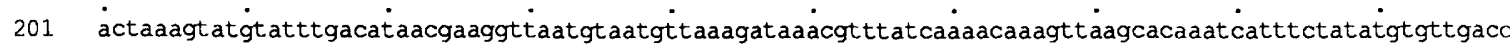

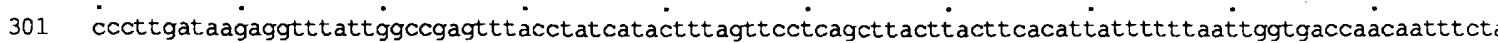

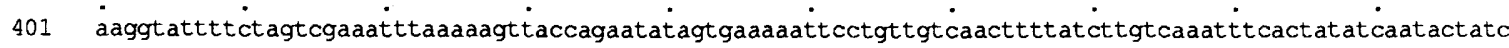
501 àttcaaatgtg்ttacgttattttatctaagagggaagacaaatcattgaatcattttcattactgttaaactgtttctctaatgaatccagtctcotto

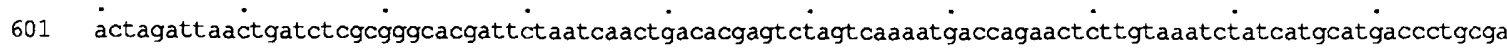
701 gaaagccacctctattctagcaagaactcaatgcaagtcaajagtgcacagattctggaaaaataataataatgtcttaattactacactctaaaaagagg

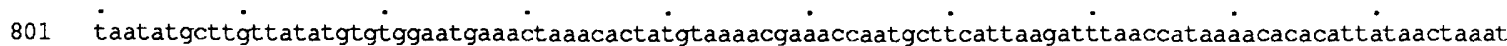
$901 \dot{g} g g a c a a a a t a t t a t c c a a c a a a c a t g c a t \dot{g} t t c c c t t t t \dot{t} a t c c a a t a t \dot{t}$ gacaattttttactcaacctttatttaagagtttacatatgcagactc

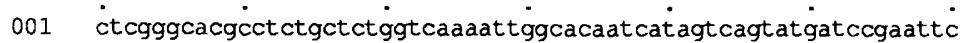
TECORI

Figure 8. Sequences of a Hboxl partial cDNA from $T$. gratilla and a corresponding region of $S$. purpuratus genomic DNA. The sequence of a $T$. gratilla Hboxl cDNA, which includes 3361 nucleotides of coding and 3 '-untranslated sequence, is shown, along with a conceptual translation. The homeo box is underlined heavily, and a short sequence immediately upstream that is conserved in many other homeo-box-containing genes is underlined thinly. (ill) The border between the separate exons encoding these conserved sequences. The sequence of a 226-nucleotide fragment of $S$. purpuratus genomic DNA is aligned with the $5^{\prime}$ end of the $T$. gratilla sequence, with endpoints indicated by brackets. Only nucleotides or amino acids that differ in $S$. purpuratus are indicated. Two codons absent from the $S$. purpuratus sequence are indicated by parentheses. The sequences of both strands of all sequences were determined. 
(Hyman 1951). In mouse and Xenopus embryos, expression of those homeo box genes analyzed to date usually is aligned along the anterior-posterior axis and on the dorsal side of the embryo; expression of individual genes is confined to different restricted regions of the embryo that do not conform to histological or morphological borders, and these regions often include derivatives of different germ layers (Gaunt et al. 1986; Condie and Harland 1987; Le Mouellic et al. 1987; Toth et al. 1987; Holland and Hogan 1988a; Sharpe et al. 1988). The first expression of Hboxl in sea urchin blastulae also reflects an early polarity in the embryo that is histologically invisible. The detailed fate map available for the sea urchin embryo [for review, see Hörstadius (1973); extended and modified for $S$. purpuratus by Cameron et al. (1987)] permits relating the region of the blastula and pluteus expressing Hbox 1 mRNA to early cleavage planes and blastomeres of the eight-cell embryo (Fig. 9). Cameron et al. (1987) showed that six of the eight-cell stage blastomeres contribute to aboral ectoderm of the pluteus and defined an oral-aboral axis that lies at a $45^{\circ}$ angle to the first two cleavage planes. The initial accumulation of Hbox 1 mRNA in (probably) all aboral ectoderm conforms to this axis: The Hboxl probe labels the future aboral side, which was termed dorsal in the early literature. This labeling pattern is typical of that observed for other mRNAs expressed in aboral ectoderm, including several that are strictly tissue specific (Lynn et al. 1983; Angerer et al. 1986; Cox et al. 1986; Hardin et al. 1988). In this respect, Hboxl expression offers an additional demonstration that cells of aboral and oral regions of the ectoderm establish distinct patterns of gene expression by early blastula stage (for review, see Angerer and Davidson 1984), and Hboxl gene activation may share elements of the same regulatory mechanism that activates other aboral ectoderm-specific genes.

Soon after its activation, however, the Hboxl gene must be subject to a unique control because it exhibits the characteristic failure of patterns of homeo box gene expression to conform to morphological borders-in this case, the future oral-aboral histological division. In contrast, all other aboral ectoderm-specific mRNAs examined thus far are present at uniform concentration in this tissue, and both increases and decreases in their concentrations also occur uniformly (Lynn et al. 1983; Angerer et al. 1986; Cox et al. 1986; Hardin et al. 1988). The unique progressive restriction of Hboxl gene expression within the aboral ectoderm reveals an unsuspected heterogeneity among cells of this cytological type, as well as an unsuspected polarity within this tissue. As shown in Figure 9, this polarity does not conform precisely to either the animal-vegetal or oralaboral embryonic axis nor does it align precisely with the anterior-posterior axis (mouth to anus). Instead, SpHboxl mRNA becomes restricted progressivley during gastrulation until it is found in the pluteus only in a region corresponding closely to that constructed from the progeny of the Va blastomere of the eight-cell embryo, which occupies the most aboral quadrant (posterior and dorsal) of the vegetal hemisphere. The signifi-
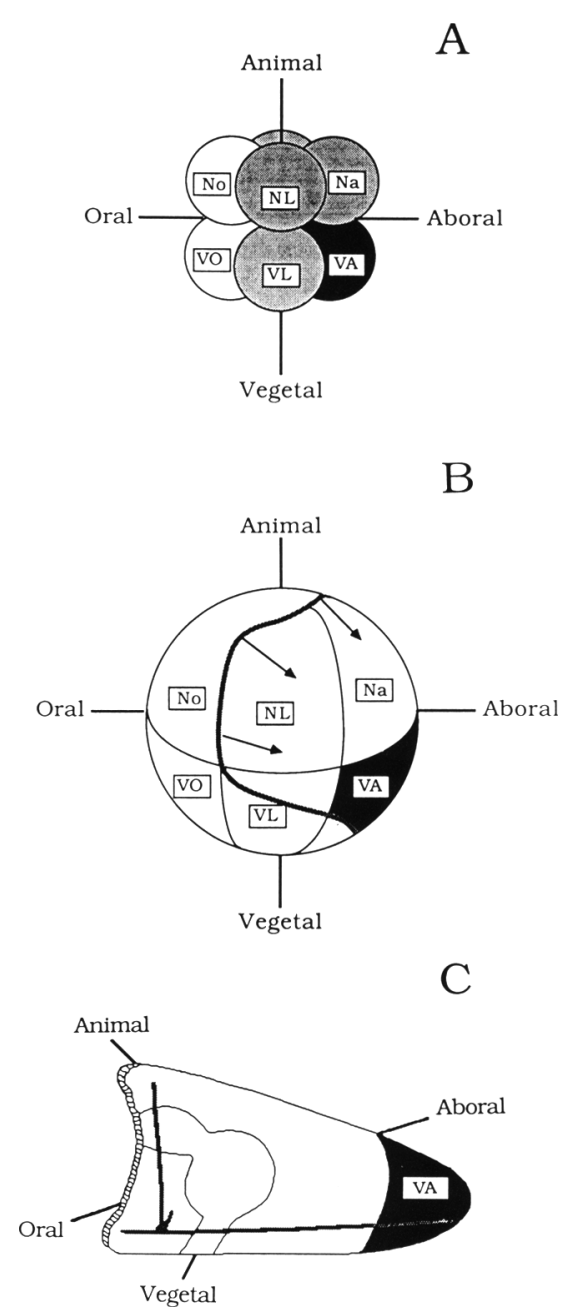

Figure 9. Relationship of spatial pattern of Hboxl expression to early cleavage planes and embryonic axes. $(A)$ The eight-cell embryo is shown with the blastomeres labeled according to the terminology of Cameron et al. (1987). The four blastomeres of the animal pole give rise exclusively to ectoderm, whereas the four blastomeres in the vegetal hemisphere contribute about half their volume to ectoderm and half to endoderm and mesenchyme. Six blastomeres contribute to aboral ectoderm, but unequally: The plane of the future oral-aboral axis lies at a $45^{\circ}$ angle to the first two meridional cleavage planes, bisecting the $\mathrm{Na}$ and VA (and No and VO) blastomeres, which give rise only to aboral ectoderm. The four lateral blastomeres (NL and VL on the future right and left sides, respectively/ yield both oral and aboral ectoderm. $(B)$ Schematic representation of the blastulastage embryo at the time of first appearance of Hboxl mRNA. The regions contributed by individual eight-cell blastomeres are labeled. The thick line represents the approximate position of the border between presumptive oral and aboral ectoderm, based on in situ hybridizations carried out in our laboratory with probes specific for aboral ectoderm. In the pluteus, this border is defined by the ciliated band. Arrows indicate the direction in which the region of aboral ectoderm hybridizing with the Hboxl probe retracts after blastula stage. $(C)$ Schematic representation of the pluteus larva. The original animal-vegetal axis is bent as a result of expansion of the ectoderm. The ciliated band outlines the oral face (left). The skeletal rods, of which only the left is shown, meet at the vertex, which is the region covered by descendents of the VA blastomere (black). 
cance and mechanism of this restriction may be similar to cases in other embryos in which there is a progressive sharpening of boundaries of homeo box mRNA accumulation. However, the orientation of restriction in urchin embryos does not correspond to that of most vertebrate homeo box message distributions described so far, which maintain static anterior borders and contract from their posterior borders (e.g., Carrasco and Malacinski 1987; Holland and Hogan 1988b).

It appears unlikely that the Hbox 1 gene product is involved in initial determination or differentiation of aboral ectoderm cells because Hboxl mRNA is present at only $\sim 1 \%$ of its peak levels when two marker genes for aboral ectoderm commitment, Specl and actin CyIIIa, are activated. Because the earliest stage at which we have demonstrated aboral ectoderm-specific accumulation of Specl and CyIIIa messages by in situ hybridization is $18 \mathrm{hr}$ (Cox et al. 1986; Hardin et al. 1988), we cannot exclude the possibility that the low levels of new transcripts detected at 9-12 hr are expressed more broadly. However, by $15 \mathrm{hr}$, the embryo has accumulated a significant fraction of the tissue-specific transcripts observed at $18 \mathrm{hr}$. This situation is similar to that in vertebrate embryos where tissue specification, determination, and initial differentiation occur before most homeo box genes are activated (for discussion, see Holland and Hogan 1988b; Harvey and Melton 1988). To examine the possibility that the Hboxl protein might be stored as a maternal product, we estimated the amount of Hboxl message in ovary and egg RNA. This mRNA was undetectable in unfertilized eggs using an RNase protection assay sufficiently sensitive to detect several hundred transcripts per egg, i.e., at a concentration lower than that of the rare maternal RNA set. We were able to detect Hboxl message in ovaries of both species, although at several orders of magnitude lower abundance than in gastrula-stage embryos. The widespread distribution of Hboxl mRNA in adult tissues, coupled with its absence from eggs, suggests that ovary transcripts are contained in tissues other than the germ line.

Although we do not favor a role for Hboxl in initial specification of cell fate, we note that studies of the developmental capacities of different parts of sea urchin embryos, alone and in abnormal combinations, have demonstrated considerable plasticity of fate in presumptive ectoderm, which decreases after the blastula stage (for review, see Hörstadius 1973). The possibility remains that the Hboxl gene product could be involved in establishing the irreversible determination of aboral ectoderm. As an alternative to a strictly developmental process, the Hboxl gene may be involved in some yet unrecognized physiological regulation. The participation of proteins containing homeo domains in physiological types of regulation is suggested by the recent demonstration of sequences related to the homeo box in the yeast PHO2 gene (Bürglin 1988). Physiological regulation also is consistent with the broad distribution of Hboxl message in adult tissues, as well as with the difference in Hboxl mRNA abundance observed in different cultures of embryos. The only other mRNA for which significant quantitative variation among different embryos has been observed is that encoding metallothionein (Angerer et al. 1986), which clearly is regulated physiologically.

At least two different mechanisms might underly the progressive spatial restriction of Hbox 1 mRNA within the aboral ectoderm. First, it might be a clonal phenomenon in which clusters of aboral ectoderm cells derived from individual early blastomeres discontinue expression of Hboxl mRNA at different times. Such a phenomenon might result in patches of different concentration of Hboxl mRNA corresponding to regions of aboral ectoderm contributed by different clones. The region of aboral ectoderm in which Hboxl mRNA persists at pluteus stage does correspond closely to the lineage derived from the $\mathbf{V a}$ blastomere of the eight-cell embryo (see Fig. 9; Cameron et al. 1987). Although less striking than at pluteus stage, some other regions of uniform intermediate labeling intensity were observed in sections of embryos at earlier stages (e.g., at the top of the gastrula in Fig. 3, row 2). A second mechanism could be based on cell-cell interactions generating a wave of inactivation of Hboxl gene expression that gradually moves through the tissue as a function of distance from some positive or negative signal at either end. Such a mechanism is consistent with gradients of labeling intensity observed in other sections. Potential sources of this polarity are the band of cells at the oral-aboral border that will form the ciliary band and the plug of mesenchyme cells around the ends of the elongating skeletal spicules at the vertex.

The conservation of temporal and spatial patterns of expression of the Hboxl gene in two sea urchin species that diverged 30-45 million years ago (Smith 1988) suggests an important function. Furthermore, the extreme conservation of sequence upstream of the homeo box suggests that biochemical functions of this protein other than DNA binding also are conserved highly. Several features of the partial protein sequence are notable. First, the sea urchin sequence contains four residues of a five-amino-acid sequence found just upstream of the homeo domains of other proteins, in which cases it is encoded by a separate exon (Mavilo et al. 1986; Krumlauf et al. 1987; Fritz and DeRobertis 1988). This sequence has been suggested to create a bend in the polypeptide that could serve to separate the homeo domain from preceding domains of the protein (Fritz and DeRobertis 1988). Second, the region upstream of the homeo domain lacks similarity to sequences found in corresponding positions in other genes containing homeo boxes, including the prd (Baumgartner et al. 1987) and POU (for review, see Herr et al. 1988) boxes described recently. However, it does encode a protein sequence unusually rich in serine and proline, as also has been reported for homeo proteins of Xenopus (Harvey et al. 1986; Condie and Harland 1987; Fritz and DeRobertis 1988), mouse (Krumlauf et al. 1987; Le Mouellic et al. 1987; Odenwald et al. 1987), and Drosophila (Poole et al. 1985; Baumgartner et al. 1987; Regulski et al. 1987; Gay et al. 1988; Krause et al. 1988). The fact that these re- 
gions share no striking similarity in specific protein sequence (except in the case of cognate genes in different organisms) suggests that high content of these amino acids per se may be a significant feature of these protein domains. In light of the recent demonstrations that the Drosophila ftz (Krause et al. 1988) and engrailed (Gay et al. 1988) homeo proteins are highly phosphorylated and that sites of modification of the latter protein are serine and threonine residues, it seems highly likely that this and other homeo proteins and possibly other DNAbinding proteins with similar amino acid composition (e.g., zinc finger-containing proteins, Boulay et al. 1987; Kinzler et al. 1988) are phosphorylated. Such modifications might constitute a flexible and efficient way to regulate the transcriptional control functions of these proteins.

\section{Methods}

\section{Embryo culture}

$S$. purpuratus specimens were obtained from Marinus, Inc. (Westchester, California) and T. gratilla specimens were collected locally. S. purpuratus embryos were cultured as described by Angerer and Angerer (1981), and T. gratilla, as described by Fregien et al. (1983).

\section{Hybridization probes}

Recombinant DNA sequences used to detect mRNAs transcribed from the Hboxl genes of $T$. gratilla and $S$. purpuratus are described in Figure 1. The templates derived from $T$. gratilla sequences include (1) an 856-bp EcoRI-HaeIII fragment derived from a genomic clone (Dolecki et al. 1986), which contains the 180-bp homeo box (solid bar) and flanking DNA composed mostly of exon sequence; (2) a 3.3-kb cDNA /sequence shown in Fig. 8), which contains 920 bp of protein-coding sequence (hatched bar), including the homeo box domain and $2137 \mathrm{bp}$ of 3 '-untranslated sequence (open bar); (3) a 284-bp EcoRI-PstI subfragment from the protein-coding region of the cDNA clone, 282 nucleotides upstream of the homeo box. Clone 4 is a 226-bp TaqI fragment derived from a $S$. purpuratus genomic DNA clone, corresponding to a portion of $T$. gratilla clone 3 . All sequences were inserted into pGem1 or pGem4Bl (Promega Biotec). To generate RNA probes, templates were restricted with EcoRI, and ${ }^{32} \mathrm{P}$ - or ${ }^{35}$ S-labeled RNA was transcribed with Sp6 RNA polymerase as described previously (Cox et al. 1984; Angerer et al. 1987). DNA probes were labeled with ${ }^{32} \mathrm{P}$ by nick translation (for Southern blots) or by synthesis primed with random oligonucleotides (Pharmacia) (for Northern blots). The Specl probe used for in situ hybridization was described by Hardin et al. (1988); a subfragment of this sequence was used for RNase protection. The actin CyIIIa probe was described by Cox et al. (1986).

\section{Southern and Northern blot analyses}

Isolation of the T. gratilla genomic DNA has been described previously (Dolecki et al. 1986) and S. purpuratus DNA was the gift of Fred Wilt (University of California, Berkley). DNAs were digested with restriction endonucleases ( $15 \mu \mathrm{g} / \mathrm{lane}$ ), electrophoresed on $0.8 \%$ horizontal agarose gels (Fregien et al. 1983), and transferred to nitrocellulose filters (Southern 1975). After baking, filters were hybridized with nick-translated template 1 , washed as described previously (Dolecki and Humphreys 1988), covered with plastic wrap, and exposed to Kodak XAR-5 film with intensifying screens at $-70^{\circ} \mathrm{C}$ for $18 \mathrm{hr}$. Specificity of hybridization was fixed by a post-hybridization wash at approximately $T_{m}-15^{\circ} \mathrm{C}$ for the homologous duplex.

RNA was extracted from tissues of adult $T$. gratilla as described by Dolecki and Humphreys (1988). Ovaries and testes were collected from animals previously induced to shed their gametes by injection of $\mathrm{KCl}$. Poly $(\mathrm{A}){ }^{+} \mathrm{RNA}(2 \mu \mathrm{g})$ was electrophoresed on each lane of a denaturing formaldehyde- $1 \%$ agarose gel and transferred to nitrocellulose as described previously (Dolecki et al. 1986). Filters were processed as described previously (Dolecki and Humphreys 1988) and exposed for 10 days at $-70^{\circ} \mathrm{C}$ with intensifying screens. The probe was clone 2 (Fig. 1) with a sp. act. of $\sim 1 \times 10^{9} \mathrm{dpm} / \mu \mathrm{g}$.

\section{Titrations and RNase protection}

Total cellular RNA was purified essentially according to Nemer et al. (1984) from S. purpuratus embryos at the indicated stages and from cell fractions of gastrulae enriched for aboral ectoderm and endoderm plus mesenchyme by a modification of the method of Harkey and Whiteley (1980). For titrations, increasing amounts $(5-25 \mu \mathrm{g})$ of RNAs were hybridized, as described previously (Lynn et al. 1983) with an excess of 32P-labeled RNA $\left(2.2 \mathrm{ng} ; 3.4 \times 10^{4} \mathrm{cpm} / \mathrm{ng}\right)$ transcribed in vitro from template 1 (Fig. 1) in pGeml (Promega Biotec) that had been linearized with EcoRI. The number of complementary mRNA molecules per embryo was calculated from the slope of the lines generated by plotting nanograms of probe hybridized versus microgram of total RNA, using values of $27 \%$ of the probe length $(180 \mathrm{bp})$ that forms an RNase-resistant hybrid, and $2.8 \mathrm{ng}$ total RNA per embryo (Goustin and Wilt 1981).

For RNase protection assays, RNA probes for the $S$. purpuratus Hboxl mRNA (Fig.1, template 4) and for the aboral ectoderm-specific Specl and actin CyIIIa mRNAs of $S$. purpuratus were synthesized at a sp. act. of $2 \times 10^{8} \mathrm{dpm} / \mu \mathrm{g}$, and fulllength transcripts were purified by electrophoresis at $60^{\circ} \mathrm{C}$ on acrylamide gels containing $8 \mathrm{M}$ urea, followed by overnight elution from the crushed excised gel band. Cellular RNAs were hybridized to probes essentially as described for titrations. After digestion with RNase A $(40 \mu \mathrm{g} / \mathrm{ml})$ and RNase T1 (750 $\mathrm{U} / \mathrm{ml}$ ), resistant duplex was purified by digestion with proteinase $\mathrm{K}$, extraction with phenol/chloroform and chloroform, and precipitation with ethanol. In all cases, a labeled RNA transcript was added as a control for recovery lexcept that shown in Fig. 5, which is controlled internallyl, during organic extraction and precipitation. Samples were electrophoresed on denaturing $5 \%$ acrylamide-urea gels at $60^{\circ} \mathrm{C}$, as described above, and signals were quantitated by densitometry of autoradiograms.

\section{Screening, subcloning, and sequencing}

RNAs labeled with ${ }^{32} \mathrm{P}$, transcribed from template 3 (see Fig. 1) and representing the region 280 nucleotides upstream from the homeo box sequence, were used to screen a $S$. purpuratus genomic library in $\lambda E M B L 3$ (kindly provided by W.H. Klein, M.D. Anderson Hospital and Tumor Institute) under conditions of reduced stringency. Hybridization was carried out at $50^{\circ} \mathrm{C}$ in $0.3 \mathrm{M} \mathrm{NaCl}, 20 \mathrm{~mm}$ Tris- $\mathrm{HCl}(\mathrm{pH} 8.0), 2 \mathrm{~mm}$ EDTA, $1 \times$ Denhardt's solution $10.02 \%$ each polyvinylpyrollidone, Ficoll, and BSA), $10 \%$ polyethylene glycol (PEG 8000 , Sigma), and $1 \%$ SDS. Plaque lifts were washed at $55^{\circ} \mathrm{C}$, as described by Church and Gilbert (1984), first with three changes of a solution containing $0.5 \%$ BSA (wt $/ \mathrm{vol}$ ), $40 \mathrm{~mm}$ sodium phosphate ( $\mathrm{pH} 6.8), 1 \mathrm{~mm}$ EDTA, and $5 \%$ SDS, and then with three changes of a solution containing $40 \mathrm{~mm}$ sodium phosphate $(\mathrm{pH} 6.8), 1 \mathrm{~mm}$ EDTA, and $1 \%$ SDS. 
To sequence the 3361-bp TgHboxl cDNA (clone 2 in Fig. 1), it was first subcloned into the EcoRI sites of $\mathrm{M} 13 \mathrm{mpl0}$ and mpll, as described previously (Dolecki and Humphreys 1988). Deletion subclones were generated by the method of Dale et al. (1985) from M13 recombinants. Single-stranded recombinant M13 DNAs were prepared as described previously (Dolecki et al. 1986) and were sequenced by the dideoxynucleotide chaintermination method (Sanger et al. 1977), using ${ }^{35}$ S-labeled deoxyadenosine 5 - $(\alpha$-thio)-triphosphate as the labeled nucleotide. A complementary $S$. purpuratus 226-bp fragment of a positive recombinant, identified by Southern blot analysis, was subcloned into pGEM1 and sequenced using ${ }^{35} \mathrm{~S}$-labeled dATP and Sequenase (United States Biochemical), primed by Sp6 and T7 primers, and terminated with dideoxynucloside triphosphates according to the supplier's protocol. Nucleotide sequence analyses were performed using the GEL, GENED, SEQ IFIND, and PEP computer programs made available through the BIONET resource.

\section{In situ hybridization}

Antisense and sense RNA probes were synthesized from template 1, truncated with EcoRI or HindIII, respectively. Transcripts were labeled with ${ }^{35}$ S]UTP to a sp. act. of $4.6 \times 10^{8}$ $\mathrm{dpm} / \mu \mathrm{g}$ (kindly provided by Dupont-NEN). Probe purification and fragment length reduction by limited alkaline hydrolysis were carried out as described by Cox et al. (1984).

Fixation and prehybridization treatments of sections of eggs and embryos were carried out as described by Angerer and Angerer (1981), except the proteinase $\mathrm{K}$ concentration was increased to $3 \mu \mathrm{g} / \mathrm{ml}$ for experiments shown in Figure 3. Sections were mounted on slides coated with polylysine, as described by Cox et al. (1986), or with 3-aminopropyl triethoxysilane, as described by Gottlieb and Glaser (1975). Hybridization was carried out as described by Cox et al. (1984), using saturating concentrations of probe $(0.26 \mu \mathrm{g} / \mathrm{ml})$ in $50 \%$ formamide, $0.3 \mathrm{M}$ $\mathrm{NaCl}, 20 \mathrm{~mm}$ Tris, $5 \mathrm{~mm}$ EDTA, $1 \times$ Denhardt's solution, and $10 \%$ dextran sulfate, supplemented with $100 \mathrm{~mm}$ DTT. The wash protocol used for ${ }^{35} \mathrm{~S}$-labeled probes is described in Angerer et al. (1987) and includes a stringent wash in 50\% formamide, $0.3 \mathrm{M} \mathrm{NaCl}, 20 \mathrm{~mm}$ Tris, $5 \mathrm{~mm}$ EDTA, and $10 \mathrm{~mm}$ DTT at $65^{\circ} \mathrm{C}$, for $15 \mathrm{~min}$ before the RNase digestion step. This condition corresponds approximately to $5^{\circ} \mathrm{C}$ below the melting temperatures of in situ hybrids containing $50 \% \mathrm{G}+\mathrm{C}$ (Cox et al. 1984). Autoradiography and staining of sections were carried out as described by Angerer and Angerer (1981).

\section{Acknowledgments}

This work was supported by grants from the National Institutes of Health to R.C.A and L.M.A. (GM-25553), G.J.D. (HD-22483), and T.H. (HD-6574). R.C.A. is the recipient of a Career Development Award from the U.S. Public Health Service (HD-00601). The BIONET resource is supported by a grant from the National Institutes of Health Division of Research Resources (RR-01685). We thank Marlene King for technical assistance and Dr. Fred Wilt for $S$. purpuratus DNA. We also thank Dupont-NEN for generously providing ${ }^{35}$ S-labeled ribonucleotides.

\section{Note}

Sequence data described in this paper have been submitted to the EMBL/GenBank Data Libraries.

\section{References}

Akam, M. 1987. The molecular basis for metameric pattern in the Drosophila embryo. Development 101: 1-22.

Angerer, L.M. and R.C. Angerer. 1981. Detection of poly $\mathrm{A}^{+}$ RNA in sea urchin eggs and embryos by quantitative in situ hybridization. Nucleic Acids Res. 9: 2819-2840.

Angerer, R.C. and E.H. Davidson. 1984. Molecular indices of cell lineage specification in the sea urchin embryo. Science 226: $1153-1160$.

Angerer, L.M., K.H. Cox, and R.C. Angerer. 1987. Identification of tissue-specific gene expression by in situ hybridization. Methods Enzymol. 152: 649-661.

Angerer, L.M., G. Kawczynski, D. Wilkinson, M. Nemer, and R.C. Angerer. 1986. Spatial patterns of expression of metallothionein mRNA in sea urchin embryos. Dev. Biol. 116: $543-547$.

Baumgartner, S., D. Bopp, M. Burri, and M.D. Noll. 1987. Structure of two genes at the gooseberry locus related to the paired gene and their spatial expression during Drosophila embryogenesis. Genes Dev. 1: 1247-1267.

Beachy, P.A., M.A. Krasnow, E.R. Gavis, and D.S. Hogness. 1988. An Utrabithorax protein binds sequences near its own and the Antennapedia P1 promoters. Cell 55: 1069-1081.

Bodner, M., J-L. Castrillo, L.E. Theill, T. Deernick, M. Ellismanand, and M. Karin. 1988. The pituitary-specific transcription factor GHF-1 is a homeo box-containing protein. Cell 55: 505-518.

Boulay, J.L., C. Dennefeld, and A. Alberga. 1987. The Drosophila developmental gene snail encodes a protein with nucleic acid binding fingers. Nature 330: 395-397.

Bürglin, T.R. 1988. The yeast regulatory gene $\mathrm{PHO} 2$ encodes a homeo box. Cell 53: 339-340.

Cameron, R.A., B. R. Hough-Evans, R.J. Britten, and E.H. Davidson. 1987. Lineage and fate of each blastomere of the eight-cell sea urchin embryo. Genes Dev. 1: 75-85.

Carrasco, A.E. and G.M. Malacinski. 1987. Localization of Xenopus homeo box gene transcripts during embryogenesis and in the adult nervous system. Dev. Biol. 121: 69-81.

Church, G.M. and W. Gilbert. 1984. Genomic sequencing. Proc. Natl. Acad. Sci. 81: 1991-1995.

Condie, B.G. and R.M. Harland. 1987. Posterior expression of a homeo box gene in early Xenopus embryos. Development 101: 93-105.

Cox, K.H., D.V. DeLeon, L.M. Angerer, and R.C. Angerer. 1984. Detection of mRNAs in sea urchin embryos by in situ hybridization using asymmetric RNA probes. Dev. Biol. 101: 485-502.

Cox, K.H., L.M. Angerer, J. Lee, E.H. Davidson, and R.C. Angerer. 1986 Cell lineage-specific programs of expression of multiple actin genes during sea urchin embryogenesis. I. Mol. Biol. 188: 159-172.

Dale, R.M., B.A. McClure, and J.P. Houchins. 1985. A rapid single-stranded cloning strategy for producing a sequential series of overlapping clones for use in DNA sequencing: Application to sequencing the corn mitocondrial 18s rDNA. Plasmid 13: 31-41.

Deschamps, J., R. DeLaaf, P. Verrijzer, M. deGauw, O. Destree, and F. Meijlink. 1987. The mouse Hox 2.3 homeo box-containing gene: Regulation in differentiating pluripotent stem cells and expression pattern in embryos. Differentiation 35: $21-30$.

Desplan, C., J. Theis, and P.H. O'Farrell. 1985. The Drosophila developmental gene, engrailed, encodes a sequence-specific DNA binding activity. Nature 318: 630-635.

-1988. The sequence specificity of homeodomain-DNA 
interaction. Cell 54: 1081-1090.

Dolecki, G.J. and T. Humphreys. 1988. An engrailed class homeo box gene in sea urchins. Gene 64: 21-31.

Dolecki, G.J., G. Wang, and T. Humphreys. 1988. Stage- and tissue-specific expression of two homeo box genes in sea urchin embryos and adults. Nucleic Acids Res. 16: 1154311558.

Dolecki, G.J., S. Wannakrairoj, R. Lum, G. Wang, H.D. Riley, R. Carlos, A. Wang, and T. Humphreys. 1986. Stage-specific expression of a homeo box-containing gene in the non-segmented sea urchin embryo. EMBO J. 5: 925-930.

Fainsod, A., L.D. Bogarad, T. Ruusala, M. Lubin, D.M. Crothers, and F.H. Ruddle. 1986. The homeo domain of a murine protein binds $5^{\prime}$ to its own homeo box. Proc. Natl. Acad. Sci. 83: 9532-9536.

Fregien, N., G.J. Dolecki, M. Mandel, and T. Humphreys. 1983. Molecular cloning of five individual stage- and tissue-specific mRNA sequences from sea urchin pluteus embryos. Mol. Cell Biol. 3: 1021-1031.

Fritz, A. and E.M. DeRobertis. 1988. Xenopus homeo box-containing cDNAs expressed in early development. Nucleic Acids Res. 16: 1453-1469.

Gaunt, S.J. 1988. Mouse homeo box gene transcripts occupy different but overlapping domains in embryonic germ layers and organs: A comparison of Hox-3.1 and Hox-1.5. Development 103: 135-144.

Gaunt, S.J., J.R. Miller, D.J. Powell, and D. Doboule. 1986. Homeo box gene expression in mouse embryos varies with position by the primitive streak stage. Nature 324: 662664.

Gay, N.J., S.J. Poole, and T.B. Kornberg. 1988. The Drosophila engrailed protein is phosphorylated by a serine-specific protein kinase. Nucleic Acids Res. 16: 6637-6647.

Gehring, W. 1987a. The homeo box: Structural and evolutionary aspects. In Molecular approaches to developmental biology, pp. 115-129, Alan R. Liss, New York.

- $1987 \mathrm{~b}$. Homeo boxes in the study of development. Science 236: 1245-1252.

Gottlieb, D. I. and L. Glaser. 1975. A novel assay of neuronal cell adhesion. Biochem. Biophys. Res. Commun. 63: 815821.

Goustin, A.S. and F.H. Wilt. 1981. Protein synthesis, polyribosomes, and peptide elongation in early development of Strongylocentrotus purpuratus. Dev. Biol. 82: 32-40.

Hardin, P.E., L.M. Angerer, S.H. Hardin, R.C. Angerer, and W.H. Klein. 1988. Spec2 genes of Strongylocentrotus purpuratus: Structure and differential expression in embryonic aboral ectoderm cells. J. Mol. Biol. 202: 417-431.

Harkey, M.A. and A.H. Whiteley. 1980. Isolation, culture, and differentiation of echinoid primary mesenchyme cells. Wilhelm Roux's Arch. Dev. Biol. 194: 377-384.

Harvey, R.P. and D.A. Melton. 1988. Microinjection of synthetic Xhox-1A homeo box mRNA disrupts somite formation in developing Xenopus embryos. Cell 53: 687-697.

Harvey, R.P., C.J. Tabin, and D.A. Melton. 1986. Embryonic expression and nuclear localization of Xenopus homeo box (Xhox) gene products. EMBO /. 5: 1237-1244.

Herr, W., R.A. Strum, R.G. Clerc, L.M. Corcoran, D. Baltimore, P.A. Sharp, H.A. Ingraham, M.G. Rosenfeld, M. Binney, G. Ruvkun, and R.L. Horvitz. 1988. The POU domain: A large conserved region in the mammalin pit-1, oct- 1 , oct- 2 and Caenorhabditis elegans unc-86 gene products. Genes Dev. 2: $1512-1515$.

Hoey, T. and M. Levine. 1988. Divergent homeo box proteins recognize similar DNA sequences in Drosophila. Nature 332: $858-861$.

Holland, P.W.H. and B.L.M. Hogan. 1988a. Spatially restricted patterns of expression of the homeo box-containing gene Hox 2.1 during mouse embryogenesis. Development 102: $159-174$.

1988b. Expression of homeo box genes during mouse development: A review. Genes Dev. 2: 773-782.

Hörstadius, S. 1973. Experimental embryology of echinoderms. Oxford University Press (Clarendon), London, New York.

Hyman, L. 1951. The invertebrates, vol. II. McGraw-Hill, New York.

Ingraham, H.A., R. Chen, H. J. Mangalam, H.P. Eisholtz, S.E. Flynn, C.R. Lin, D.M. Simmons, L. Swanson, and M.G. Rosenfeld. 1988. A tissue-specific transcription factor containing a homeodomain specifies a pituitary phenotype. Cell 55: 519-529.

Kessel, M., F. Schulze, M. Fibi, and P. Gruss. 1987. Primary structure and nuclear localization of a murine homeodomain protein. Proc. Natl. Acad. Sci. 84: 5306-5310.

Kinzler, K.W., J.M. Ruppert, S.H. Bigner, and B. Vogelstein. 1988. The GL1 gene is a member of the Krüppel family of zinc finger proteins. Nature 332: 371-374.

Krause, J.M., R. Klemenz, and W.J. Gehring. 1988. Expression, modification and localization of the fushi tarazu protein in Drosophila embryos. Genes Dev. 2: 1021-1036.

Krumlauf, R., P.W. Holland, J.H. McVey, and B.L.M. Hogan. 1987. Developmental and spatial patterns of expression of the mouse homeo box gene, Hox 2.1. Development 99: $603-617$.

Le Mouellic, H., H. Condamine, and P. Brulet. 1987. Pattern of transcription of the homeo-gene Hox 3.1 in the mouse embryo. Genes Dev. 2: 125-135.

Levine, M. and T. Hoey. 1988. Homeobox proteins as sequencespecific transcription factors. Cell 55: 537-540.

Lynn, D.A., L.M. Angerer, A.M. Bruskin, W.H. Klein, and R.C. Angerer. 1983. Localization of a family of mRNAs in a single cell type and its precursors in sea urchin embryos. Proc. Natl. Acad. Sci. 80: 2656-2660.

Mavilo, F., A. Simeone, A. Giampaolo, A. Faiella, V. Zappavigna, D. Acampora, G. Poeana, G. Russo, C. Peschle, and E. Boncinelli. 1986. Differential and stage-related expression in embryonic tissues of a new human homeo box gene. Nature 324: 664-668

Nemer, M., E. C. Travaglini, E. Rondinelli, and J. D'Alonzo. 1984. Developmental regulation, induction, and embryonic tissue specificity of sea urchin metallothionein gene expression. Dev. Biol. 102: 471-482.

Odenwald, W.F., C.F. Taylor, F.J. Palmer-Hiss, V. Friedrich, Jr., M. Tani, and R.A. Lazzarini. 1987. Expression of a homeo domain protein in noncontact-inhibited cultured cells and postmitotic neurons. Genes Dev. 1: 482-496.

Poole, S., L.M. Kouvar, B. Drees, and T. Kornberg. 1985. The engrailed locus of Drosophila: Structural analysis of an embryonic transcript. Cell 40: 37-43.

Regulski, M., N. McGinnis, R. Chadwick, and W. McGinnis. 1987. Developmental and molecular analysis of Deformed, a homeotic gene controlling Drosophila head development. EMBO J. 6: 767-777.

Rubin, M.R., W. King, L.E. Toth, I.C. Sawczuk, M.S. Levine, P. D'eustachio, and M.C. Nguyen-huu. 1987. The murine Hox-1.7 homeobox gene: Cloning, chromosomal location, and expression. Mol. Cell. Biol. 7: 3836-3841.

Sanger, R., S. Nicklen, and A.R. Coulson. 1977. DNA sequencing with chain-terminating inhibitors. Proc. Natl. Acad. Sci. 74: 5463-5467.

Scott, M.P. and S.B. Carroll. 1987. The segmentation and homeotic network in early Drosophila development. Cell 51: 689-698.

Sharpe, P.T., J.R. Miller, E.P. Evans, M.D. Burtenshaw, and S.J. 
Gaunt. 1988. Isolation and expression of a new mouse homeo box gene. Development 102: 397-407.

Smith, A.B. 1988. Phylogenetic relationships, divergence times, and rates of molecular evolution for camerodont sea urchins. Mol. Biol. Evol. 5: 345-365.

Southern, E.M. 1975. Detection of specific sequences among DNA fragments separated by gel electrophoresis. J. Mol. Biol. 98: 503-517.

Toth, L.E., K. Slawin, J.E. Pintar, and M.C. Nguyen-Huu. 1987. Region-specific expression of mouse homeo box genes in the embryonic mesoderm and central nervous system. Proc. Natl. Acad. Sci. 84: 6790-6794.

Utset, M.F., A. Awgulewitsch, F.W. Ruddle, and W. McGinnis. 1987. Region-specific expression of two mouse homeo box genes. Science 235: 1379-1382.

Way, J.C. and M. Chalfie. 1988. mec-3, a homeo box-containing gene that specifies differentiation of the touch receptor neurons in C. elegans. Cell 54: 5-16. 


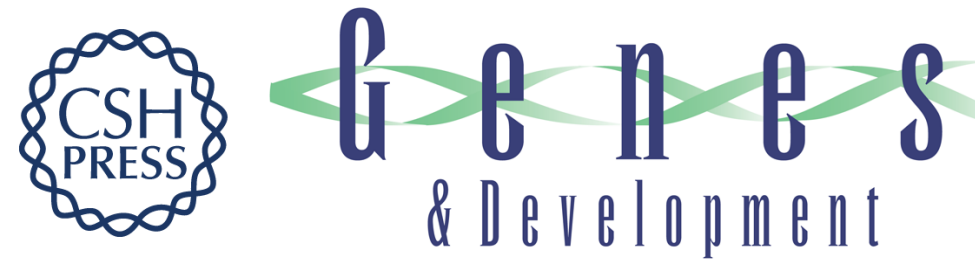

\section{Progressively restricted expression of a homeo box gene within the aboral ectoderm of developing sea urchin embryos.}

L M Angerer, G J Dolecki, M L Gagnon, et al.

Genes Dev. 1989, 3:

Access the most recent version at doi:10.1101/gad.3.3.370

References This article cites 62 articles, 22 of which can be accessed free at:

http://genesdev.cshlp.org/content/3/3/370.full.html\#ref-list-1

License

Email Alerting

Service

Receive free email alerts when new articles cite this article - sign up in the box at the top right corner of the article or click here.

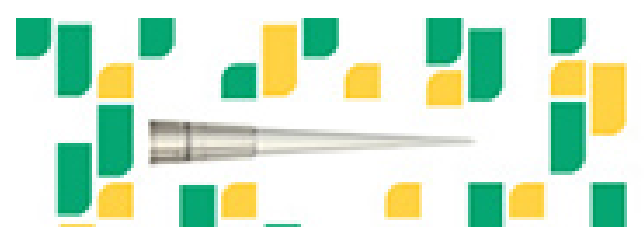

Focused on your science. 